\title{
Correction to: $\mathrm{CXCL} 10$ could drive longer duration of mechanical ventilation during COVID-19 ARDS
}

\author{
Mathieu Blot ${ }^{1,2^{*}}$, Marine Jacquier ${ }^{2,9}$, Ludwig-Serge Aho Glele ${ }^{10}$, Guillaume Beltramo ${ }^{3}$, \\ Maxime Nguyen ${ }^{2,4}$, Philippe Bonniaud ${ }^{3}$, Sebastien Prin ${ }^{9}$, Pascal Andreu ${ }^{9}$, Belaid Bouhemad ${ }^{2,4}$, \\ Jean-Baptiste Bour ${ }^{5}$, Christine Binquet ${ }^{6}$, Lionel Piroth ${ }^{1,6}$, Jean-Paul Pais de Barros ${ }^{2,7}$, David Masson ${ }^{2,8}$, \\ Jean-Pierre Quenot ${ }^{2,6,9}$, Pierre-Emmanuel Charles ${ }^{2,9}$ and Pneumochondrie Study Group
}

\section{Correction to: Crit Care (2020) 24:632}

https://doi.org/10.1186/s13054-020-03328-0

Following publication of the original article [1], the authors identified an error in the affiliations.

All the changes requested are implemented in this correction and the original article [1] has been corrected.

\section{Reference}

1. Blot M, Jacquier M, Aho Glele LS, et al. CXCL10 could drive longer duration of mechanical ventilation during COVID-19 ARDS. Crit Care. 2020;24:632. https://doi.org/10.1186/s13054-020-03328-0.

\section{Publisher's Note}

Springer Nature remains neutral with regard to jurisdictional claims in published maps and institutional affiliations.

\begin{abstract}
Author details
${ }^{1}$ Infectious Diseases Department, Dijon Bourgogne University Hospital, Dijon, France. ${ }^{2}$ INSERM, LNC UMR 1231, FCS Bourgogne-Franche Comté LipSTIC LabEx, Dijon, France. ${ }^{3}$ Department of Pneumology, Dijon Bourgogne University Hospital, Dijon, France. ${ }^{4}$ Anesthesiology and Critical Care Department, Dijon Bourgogne University Hospital, Dijon, France. ${ }^{5}$ Laboratory of Virology, Dijon Bourgogne University Hospital, Dijon, France. ${ }^{6}$ INSERM, CIC1432, Clinical Epidemiology Unit, Dijon Bourgogne University Hospital, Clinical Investigation Center, Clinical Epidemiology/Clinical Trials Unit, Dijon, France. ${ }^{7}$ Lipidomic Analytic Unit, University Bourgogne Franche-Comté, Bâtiment B3, Bvd. Maréchal de Lattre de Tassigny, 21000 Dijon, France. ${ }^{8}$ Laboratory of Clinical Chemistry, Dijon Bourgogne University Hospital, Dijon, France. ${ }^{9}$ Department of Intensive Care, Dijon Bourgogne University Hospital, Dijon, France. ${ }^{10}$ Epidemiology and Hospital Hygiene Department, Dijon Bourgogne University Hospital, Dijon, France.
\end{abstract}

Published online: 13 April 2021

The original article can be found online at https://doi.org/10.1186/s13054020-03328-0.

*Correspondence: mathieu.blot@chu-dijon.fr

${ }^{1}$ Infectious Diseases Department, Dijon Bourgogne University Hospital, Dijon, France

Full list of author information is available at the end of the article original author(s) and the source, provide a link to the Creative Commons licence, and indicate if changes were made. The images or other third party material in this article are included in the article's Creative Commons licence, unless indicated otherwise in a credit line to the material. If material is not included in the article's Creative Commons licence and your intended use is not permitted by statutory regulation or exceeds the permitted use, you will need to obtain permission directly from the copyright holder. To view a copy of this licence, visit http://creativecommons.org/licenses/by/4.0/. The Creative Commons Public Domain Dedication waiver (http://creativeco mmons.org/publicdomain/zero/1.0/) applies to the data made available in this article, unless otherwise stated in a credit line to the data. 